\title{
Winchester: A City of Two Planned Towns
}

\author{
Martin Biddle
}

The principal streets within the walls of Winchester form today an ancient and orderly pattern. There are four elements. The spine is High Street running downhill from West Gate to East Gate, and beyond to the bridge across the River Itchen. Back streets run close behind and parallel to High Street on either side. North-south streets run at right-angles from High Street out to the line of the city walls. To north and south their ends are linked by a street which ran, and in part still does run, around the inside of the city walls. This elegant and logical system is first displayed on John Speed's map of Winchester, published in 1611 (Fig. 2.1). ${ }^{1}$

In the 1870 s the Ordnance Survey mapped the city at the scale of 1:500, the sheets of which were published at this and reduced scales in the following years. The sight of the surveyors at work and the meticulous accuracy and extraordinary detail of their published sheets can only have increased interest in the historical topography of the city. In 1890 the then Dean of Winchester, G.W. Kitchin, while reasonably cautious about the nature of Venta Belgarum, Roman Winchester, published a detailed "Map of Norman Winchester, A.D. 1119," which he based on the Winton Domesday, a written survey drawn up about 1110 which he now set in the context of the mapped city (Fig. 2.2). ${ }^{2}$ There are many points of detail which later work would correct, but it was a pioneering attempt.

So too was Francis Haverfield's account of "Winchester-Venta Belgarum," published in 1900 with for the first time a plan of Winchester "showing Roman remains." This has the approach roads from north, west, and south (but not the east) and shows the Roman city wall in red, but otherwise only individual

1 John Speed, "Hantshire divided and described," Theatre of the Empire of Great Britaine (London, 1611). For Speed's map and the maps of Godson $175^{\circ}$ and Milne 1793, with full references, see Martin Biddle and Derek Keene, eds., Winchester, The British Historic Towns Atlas VI, Winchester Studies 11 (Oxford, 2017), Pl. 1, nos. 2-4. (hereafter WS 11)

2 G.W. Kitchin, Winchester (Historic Towns, ed. E.A. Freeman and W. Hunt), 2nd ed. (London, 189o), folding map facing p. 72. For the Winton Domesday, see Martin Biddle, ed., Winchester in the Early Middle Ages: An Edition and Discussion of the Winton Domesday, Winchester Studies 1 (Oxford, 1976). (hereafter WS 1) 


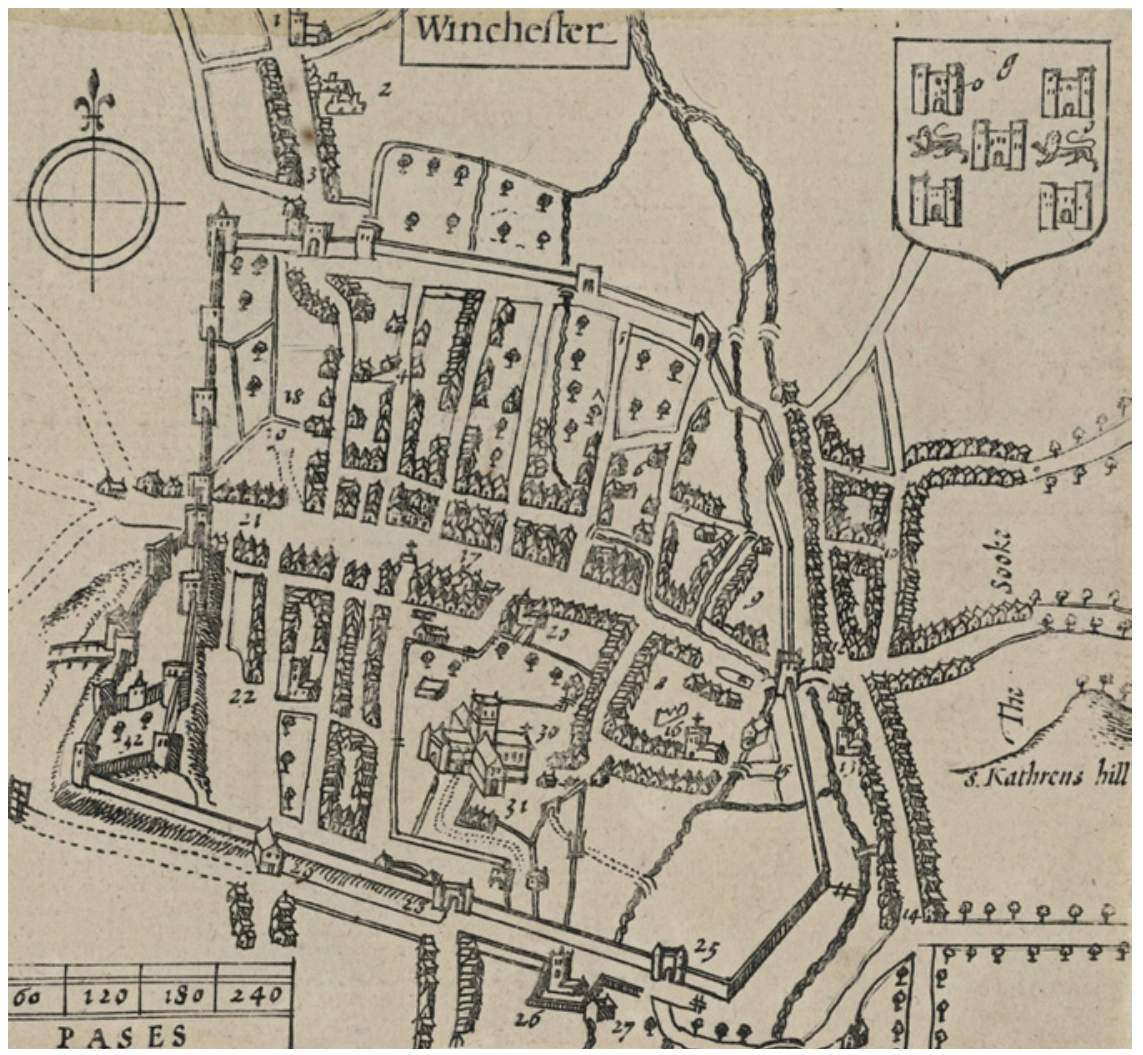

FIGURE 2.1 Winchester 1611, from John Speed, "Hantshire divided and described," Theatre of the Empire of Great Britaine PRIVATE COLLECTION

spot finds of "Buildings," "Graves," and "Other remains," with no sign of any internal streets. ${ }^{3}$

Very different was the plan of "Roman Winchester A.D. 43-410," drawn in 1909 and published in 1914 by the Winchester printer and publisher, William Thorn Warren (Fig. 2.3). "Winchester, as it exists today [he wrote], in its general plan of the older streets, is almost identical with what it was when the Roman cohorts were here stationed." Thus, all four elements of the present street plan (High Street, back streets parallel to either side, north-south streets, and wall street) and the defences of the medieval castle are taken as Roman in

3 F. Haverfield, "Romano-British Hampshire: 4. Winchester-Venta Belgarum," in $v c H$ Hants 1 (London, 1900), pp. 285-93, with plan opposite p. 286.

4 Wm. Thorn Warren, Notes from the History of Winchester (Winchester, 1914), pp. 5-8, with folding plan before title page. 


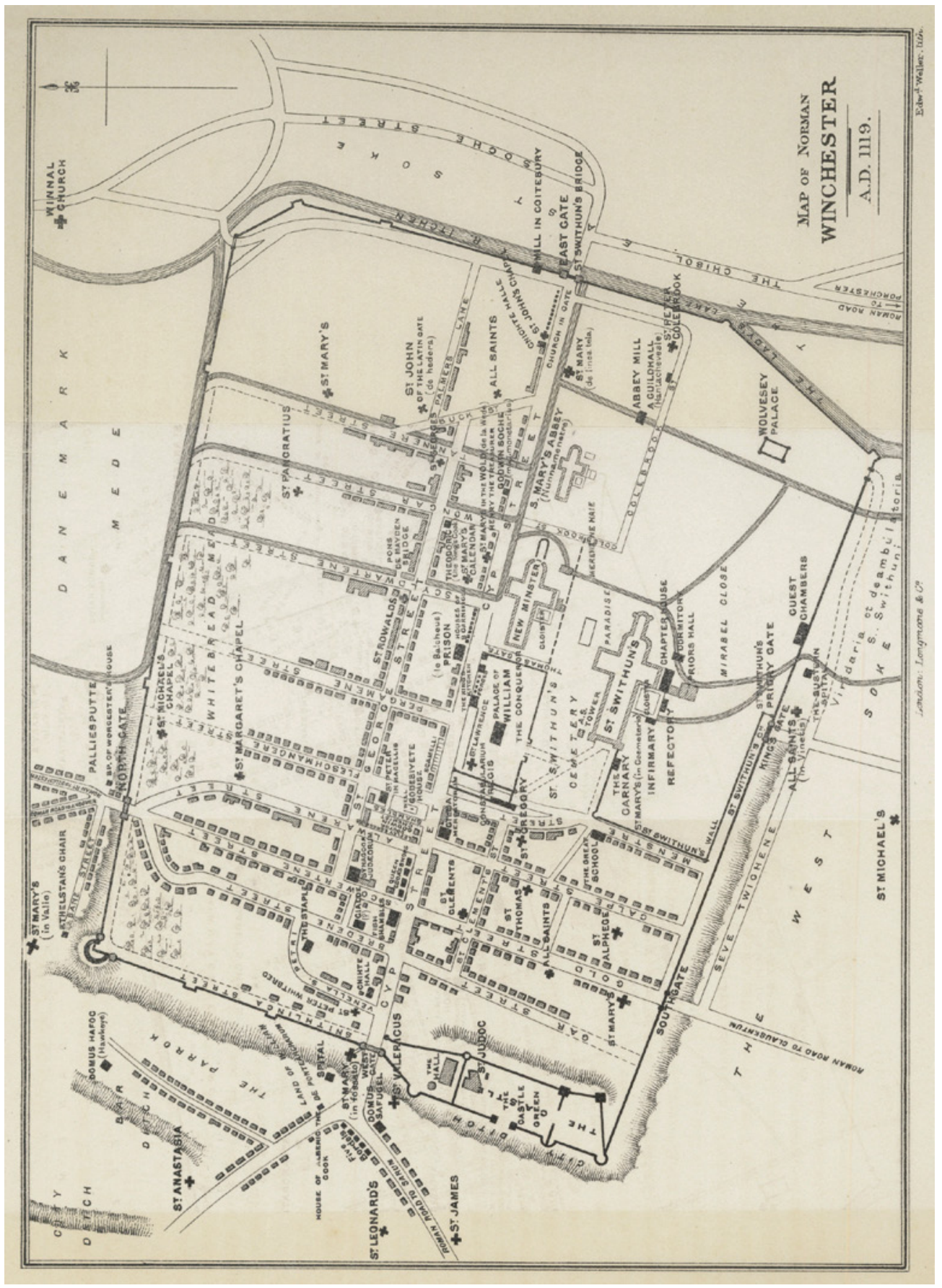

D 


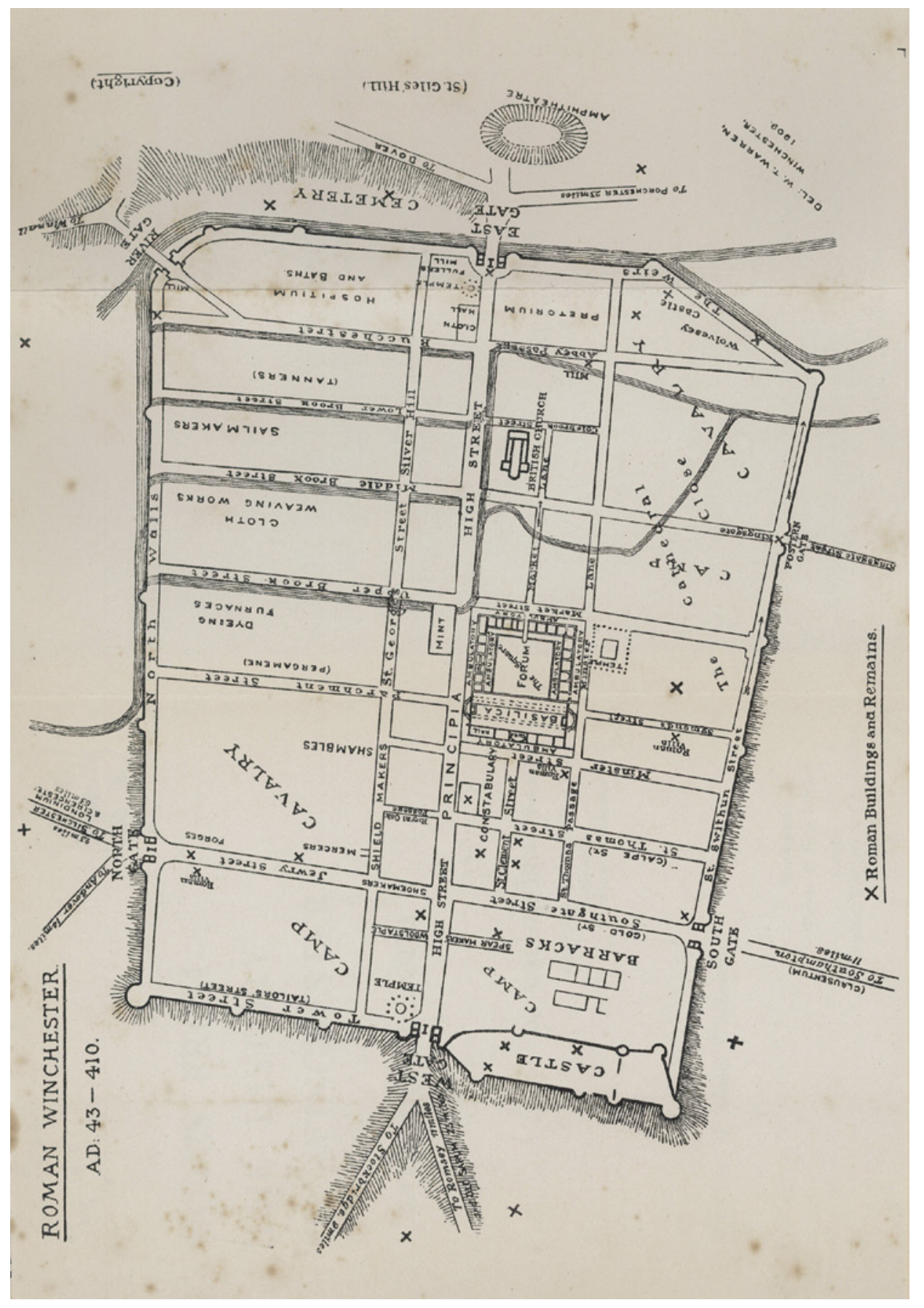

ปే 
origin, and areas are assigned to "cavalry" and "camp." This is all fancy, but the forum is in the right place and its plan and the plan of the "British church" are clearly derived from what had been revealed by the then recent excavations at Silchester, as are the in-turned plans of the four principal gates. ${ }^{5}$ It is all the stranger that Warren ignored the very regular grid of Silchester's Roman streets in favour of a Roman origin for the streets of medieval and modern Winchester.

In the thirty or so years which followed, little was learnt about the history and nature of Winchester's streets. Sydney Ward-Evans (c.1883-1943), who tried in his own way to record and salvage archaeological information and finds encountered during building works, seems to have supported Warren's view that "the main elements of the Roman town plan ... were largely reflected by those of the medieval city". 6

Much changed with the appointment in 1947 of Frank Cottrill (1908-84) as the first professional curator of the Winchester City Museum. ${ }^{7}$ His previous posts as "Investigator of Buildings" in the City of London from 1934 and to the new post of "Archaeologist" at the Leicester Museum from 1938, gave him "an impressive record of excavation experience," especially in the recording of archaeological features exposed in the construction of new buildings. These skills were fully realised in Winchester from 1947 onwards, both in his own meticulously recorded observations, but also in his encouragement of the first ever proper archaeological excavations in the city. A particular aspect was Cottrill's observation and record of service trenches dug along the streets for the insertion or repair of water, gas, electricity, and telephone cables. Sadly, observation and record of such intrusions no longer continues except in the rare cases when an archaeological condition is imposed as part of the planning process. Cottrill watched them all, especially down the north side of High Street

5 Warren's information on Silchester will have been taken from F. Haverfield, "Romano-British Hampshire: 2. Silchester," in $v c H$ Hants 1, pp. 271-84; and more particularly from G.E. Fox and W.H. St. J. Hope, "The Romano-British Town of Calleva Atrebatum at Silchester," in vcH Hants

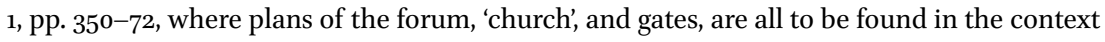
of a regular grid of Roman streets on the coloured folding plan of the Roman town facing p. 350 .

6 Kenneth E. Qualmann, "Roman Winchester," in Roman Towns: the Wheeler Inheritance. A Review of 50 Years' Research, ed. Stephen J. Greep, свA Research Report 93 (York, 1993), pp. 6677, at p. 66 and Fig. 2. See also below, p. 31.

7 Elizabeth Lewis, "Frank Cottrill, MA, FMA, FSA: An Appreciation," in John Collis et al., Winchester Excavations 1949-1960, Volume III: Excavations in St Georges Street and the High Street (unpublished typescript in Winchester Research Unit (WRU) and Winchester Museum Service (WMS) archive), pp. 11-15. 
where the discovery of Roman buildings showed conclusively that the Roman street ran not on the line of the present High Street but to its south, a situation confirmed in the excavation he arranged on the site of St Maurice's Church in $1959 .{ }^{8} \mathrm{~A}$ few other observations of Roman streets were made by Cottrill or in excavations commissioned by him, but apparently not sufficient to raise the issue of the relationship of the Roman to the Anglo-Saxon street pattern.

The first plan of the streets of Roman Venta Belgarum based on archaeological evidence "as known at the end of 1962" was published that year. ${ }^{9} \mathrm{~A}$ more detailed plan based on Cottrill's earlier observations and excavations up to 1965 followed..$^{10}$ Plans of the street pattern of Late Saxon and Norman Winchester were published following the excavations of $1966 .{ }^{11}$ By 1967 it was clear that the Anglo-Saxon streets did not follow the Roman pattern but formed a separate and distinctive system which has survived in all essentials to the present day. This was demonstrated the following year in a series of eight plans published by the Winchester Excavations Committee tracing the development of Winchester from prehistory to the 19th century (see Fig. 2.4). ${ }^{12}$

However, in 1995-96 the Winchester Museums Service (wMS) published a new plan of Roman Winchester (Fig. 2.5) comprising two distinct elements: an earlier system of thirty long narrow blocks (insulae) in the sloping western half of the walled area and a later system of fifteen larger square blocks in the lower

8 For a plan showing the relationship of the Roman west-east street to the church and to High Street, see Martin Biddle and R.N. Quirk, "Excavations near Winchester Cathedral, 1961," First Interim Report, Archaeological Journal 119 (1962), 151-53, Fig. 2 and Pl. VIII A (hereafter I Interim).

9 I Interim, Fig. 1. See also Patrick Ottaway, Winchester, St Swithun's "City of Happiness and Good Fortune" An Archaeological Assessment (Oxford, 2017), p. 83.

10 Martin Biddle, "Excavations at Winchester 1962-63. Second Interim Report," AntJ 44 (1964), 214-17, Fig. 1 (hereafter II Interim); "Excavations at Winchester 1964. Third Interim Report," AntJ 45 (1965), Fig. 1 (hereafter III Interim); "Excavations at Winchester 1965. Fourth Interim Report," AntJ 46 (1966), Fig. 1 (hereafter IV Interim).

11 Martin Biddle, "Excavations at Winchester 1966. Fifth Interim Report," AntJ 47 (1967), 277, cf. Figs. 1 and 2 (hereafter $v$ Interim).

12 WS 11, as n. 1, Fig. 1. This was first published in Martin Biddle, "Excavations in Winchester 1967. Sixth Interim Report," AntJ 48 (1968), Fig. 1 (hereafter VI Interim) and updated on several subsequent occasions, notably by the discovery in 1969 that the west wall of the Roman town formed a large salient south of West Gate which was followed by the western defences of the Norman and later castle: Martin Biddle, "Excavations at Winchester 1969. Eighth Interim Report," AntJ, 50 (1969), 281-85, Figs 1 and 2, and Pl. XxxVIII (hereafter VIII Interim). See also Martin Biddle, "The Study of Winchester: Archaeology and History in a British Town," Proceedings of the British Academy 69 (1983), 93-135, Fig. 2. 


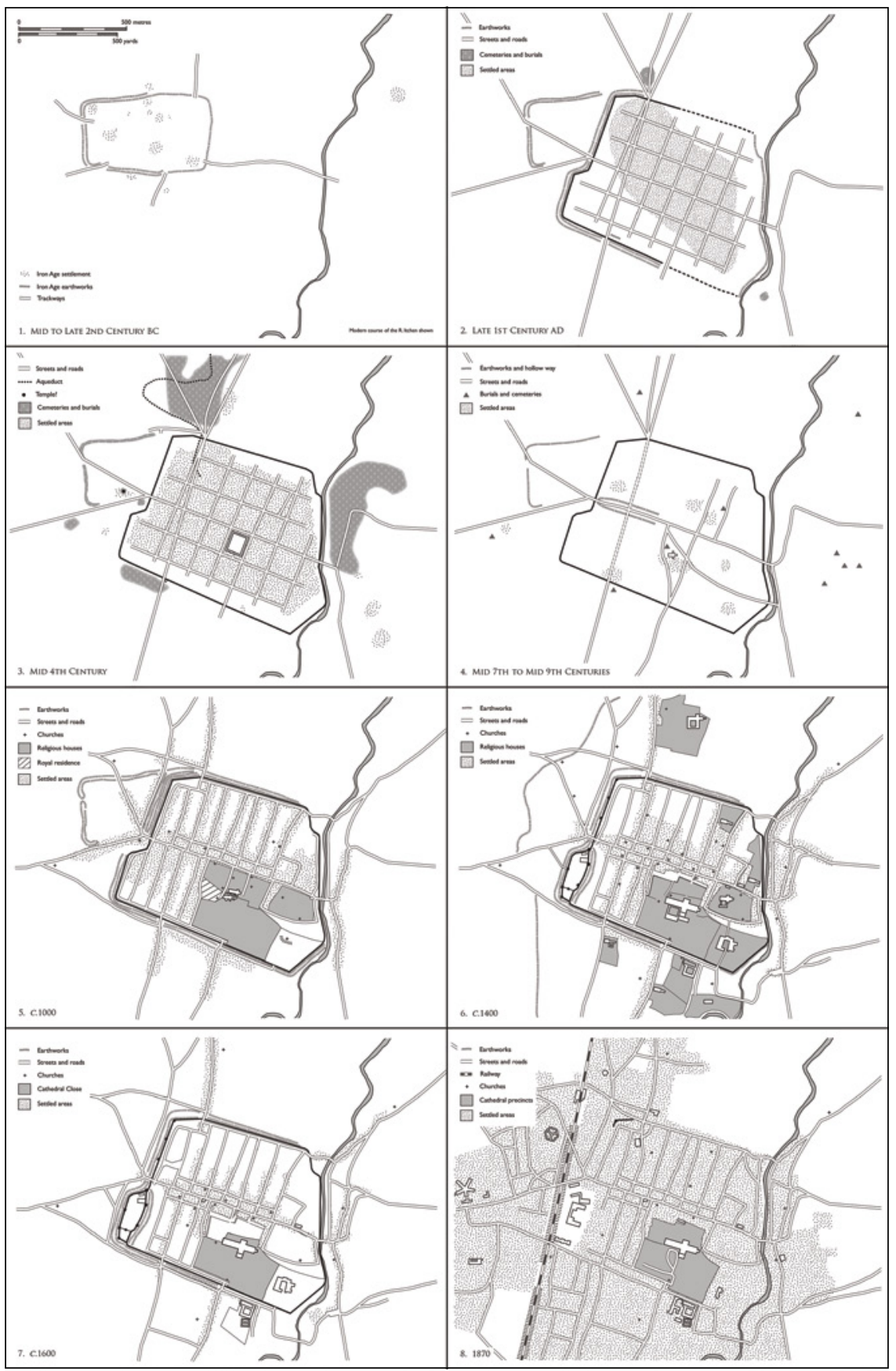

FIGURE 2.4 Winchester, the development of the city from the mid to late 2nd century в.C. to 1870, from WS 11 (Winchester Atlas) (Oxford, 2017), Fig. 1. Drawn by Giles Darkes (C) WINCHESTER EXCAVATIONS COMMITTEE AND THE HISTORIC TOWNS TRUST 


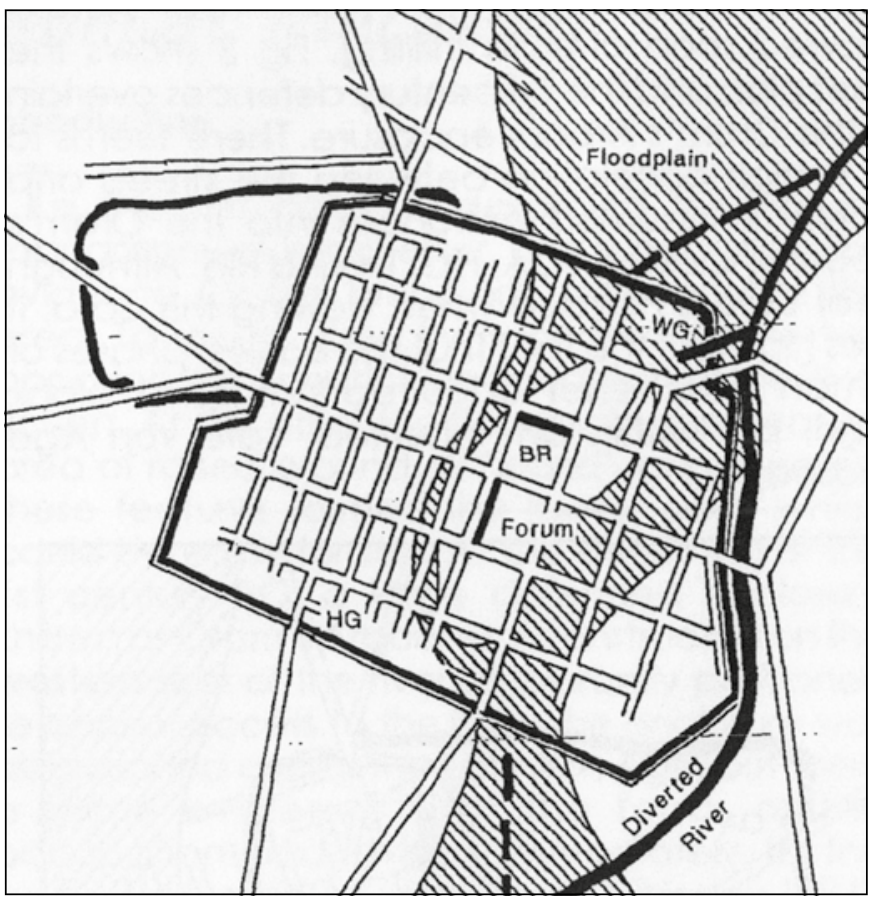

FIGURE 2.5 Winchester, supposed plan of the Roman streets, from wMS Newsletter 22 (August 1995), p. 6, Fig. 4

area to the east. ${ }^{13}$ The long narrow insulae were proposed on the basis of a single excavation close to South Gate, where the supposed north-south street is at best a lane or track.

Although no Romano-British town is known to have had a plan of this kind, ${ }^{14}$ such a plan subsequently appeared in the Winchester Museums Service's own publications ${ }^{15}$ and in the reports of outside bodies undertaking

13 Graham Scobie, “Topography and Development," WMS Newsletter, nos 21-24 (1995-96), esp. 22 (August 1995), 4-9.

14 John Wacher, The Towns of Roman Britain, 2nd ed. (London, 1995), passim. The plan of Roman Winchester (Fig. 132) was revised for this edition to reflect the views of the "Winchester Museum Service Archaeology Unit."

15 K.E. Qualmann et al., Oram's Arbour (Winchester, 2004), Fig. 39; H. Rees et al., Artefacts and Society in Roman and Medieval Winchester (Winchester, 2008), Fig. 2; M. Maltby, Feeding a Roman Town (Winchester, 2010), Figs 2, 3, and 12; P.J. Ottaway et al., The Roman Cemeteries and Suburbs of Winchester (Winchester, 2012), Figs 5, 6, 96, and 126. 
contract excavations in advance of development. ${ }^{16}$ The superb quality of the draughtsmanship and presentation of the plans in the two volumes published by Oxford Archaeology in 2010 and 2011 gives the evidence they present for the Roman street-plan a wholly undeserved authority. This unsatisfactory plan (which also shows an island in the middle of Winchester for which there is no valid evidence) has continued to be used despite the publication of the archaeological and documentary evidence presented by the Winchester Excavations Committee as long ago as 1968. This plan has been corrected by the publication in 2017 of Winchester: An Archaeological Assessment $t^{17}$ and by subsequent publications from the Winchester Excavations Committee, including The Winchester Historic Towns Atlas. ${ }^{18}$

The only Roman element shadowed by the Anglo-Saxon plan is the route downhill from West Gate to East Gate and over the crossing of the river Itchen. Here too the Roman line has been lost as the present High Street veers away to the north ${ }^{19}$ making for a crossing of the Itchen some twelve metres north of the probable site of the Roman crossing, perhaps as a result of the loss of a probable Roman bridge.

The Roman streets seem to have been laid out in the seventies or eighties of the ist century A.D., and to have lasted into some date in the 5 th century or even later (Fig. 2.6). When the church later known as Old Minster was built about the middle of the 7 th century, it was built at an angle across a Roman east-west street, the presence of which was ignored and had clearly been forgotten. The relationship of the minster to the underlying Roman street, and of the layout of the Anglo-Saxon street-plan as a whole to the pattern of the Roman streets, is now well known (Fig. 2.7) and shows conclusively the very different character of the two layouts. ${ }^{20}$

In this contribution for Barbara Yorke, who has done so much to illuminate the history and achievements of Anglo-Saxon Wessex and of England, the

16 Paul Booth et al., The Late Roman Cemetery at Lankhills, Winchester: Excavations 2000-2005, Oxford Archaeology Monograph 10 (Oxford, 2010), Fig. 1.4; Ben M. Ford et al., Winchester: a City in the Making, Oxford Archaeology Monograph 12 (Oxford, 2011), Fig. 1.4.

17 Ottaway, Winchester, Figs 3.7, 3.12, pp. 98-101.

18 WS 11, Map 2, Figs 1, 4, 6 and 10.

19 See above, p. 31, n. 8.

20 For detailed plans of Winchester $c .350, c .930$, and $c .1000$ at a scale of 1:4000, see WS 11, Maps 2-4. For the Roman and post-Roman periods, see pp. 9-12 and 20-25, Figs 4, 6, 10, and 15. For the Anglo-Saxon layout, see pp. 2 6-29, Fig. 16 (reproduced here as Fig. 2.8), and also the Gazetteer pp. 68-69. 


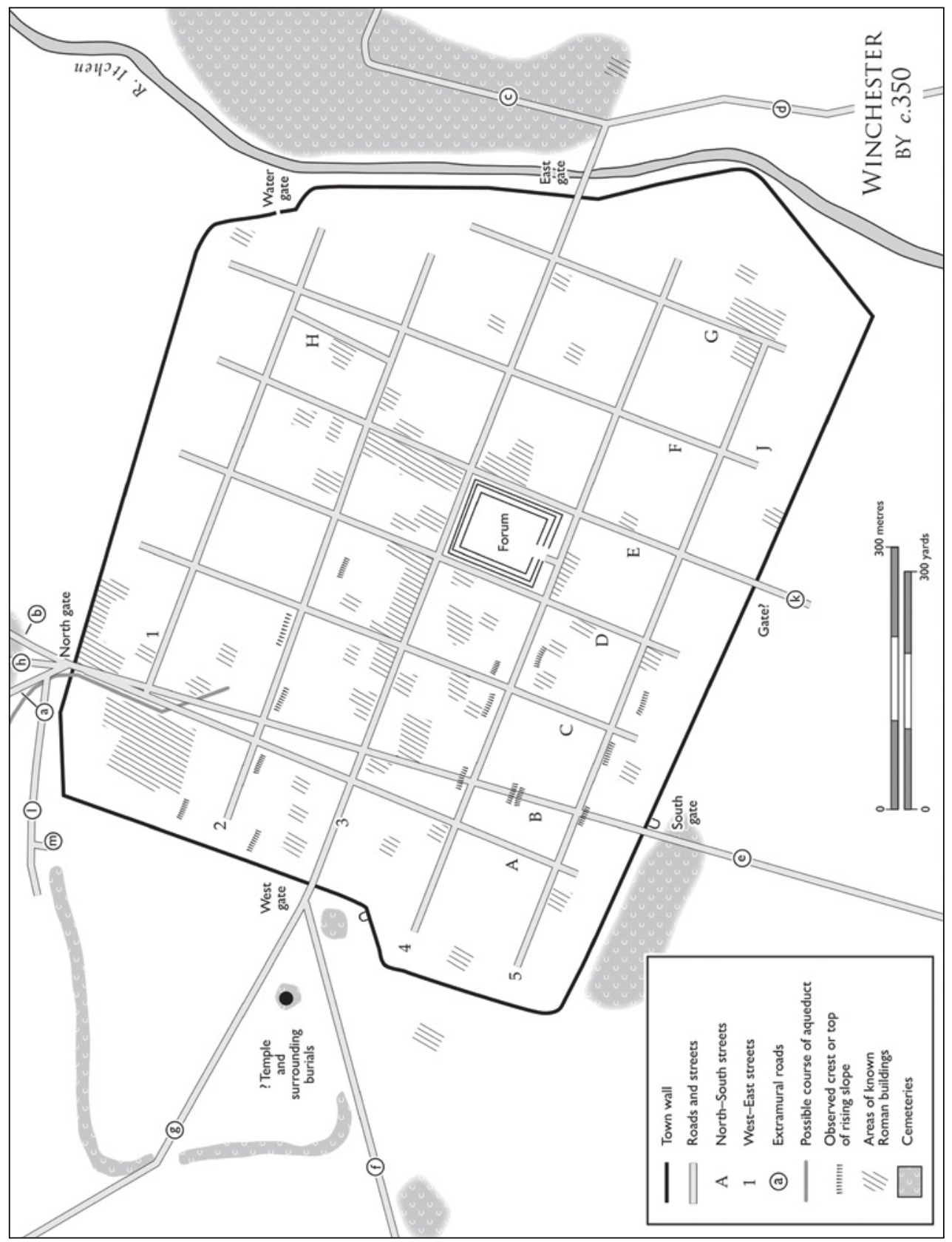

 


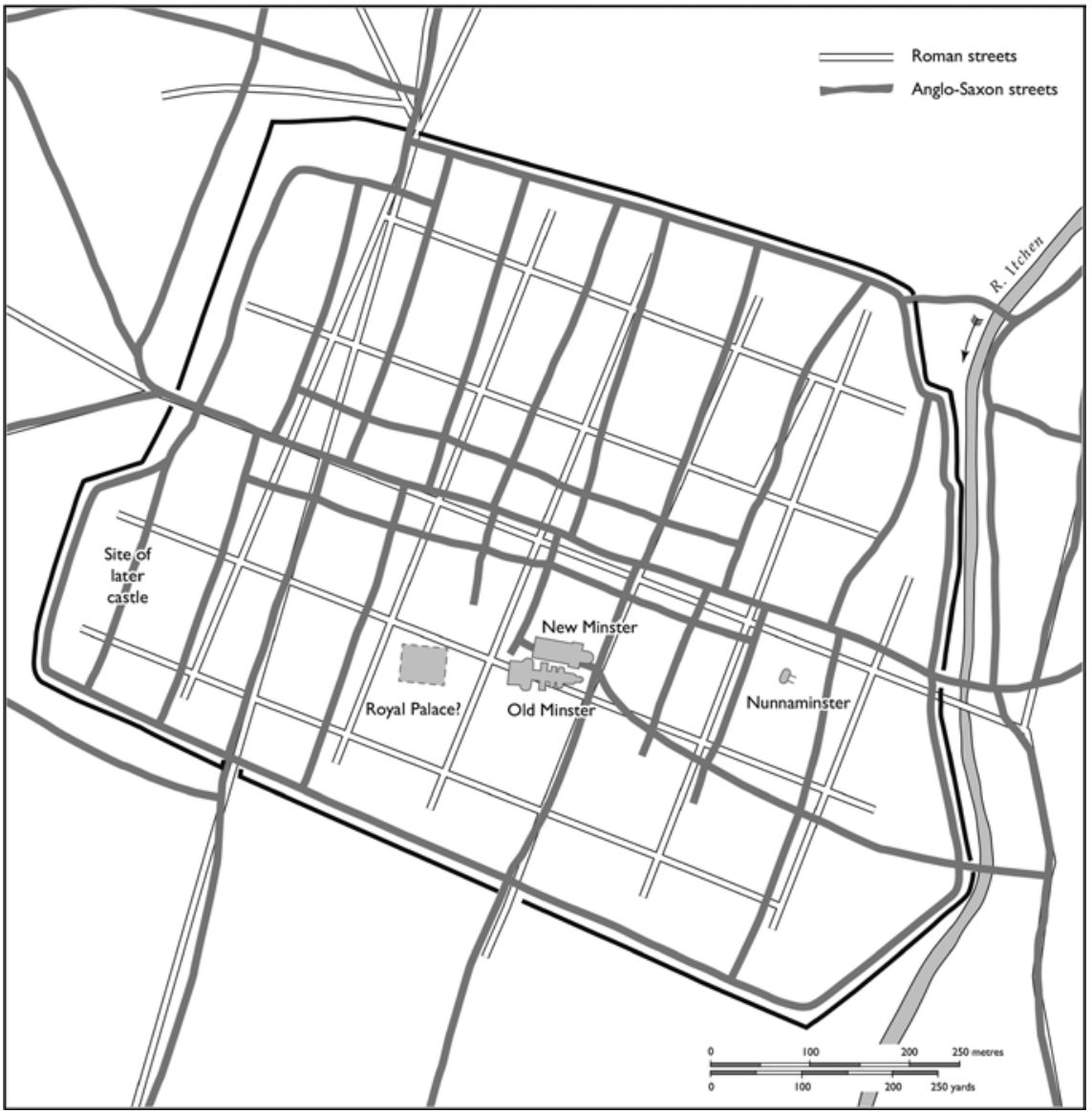

FIGURE 2.7 Winchester, the Anglo-Saxon and Roman street plans overlain. Drawn by Giles Darkes, 2017 (C)WINCHESTER EXCAVATIONS COMMITTEE

written, archaeological, and numismatic evidence for the individual streets of Anglo-Saxon Winchester are brought together for the first time in Appendices $\mathrm{A}$ and B, which follow (Fig. 2.8). ${ }^{21}$

21 I am most grateful to Clare Chapman for her assistance in editing this article and its appendices. 


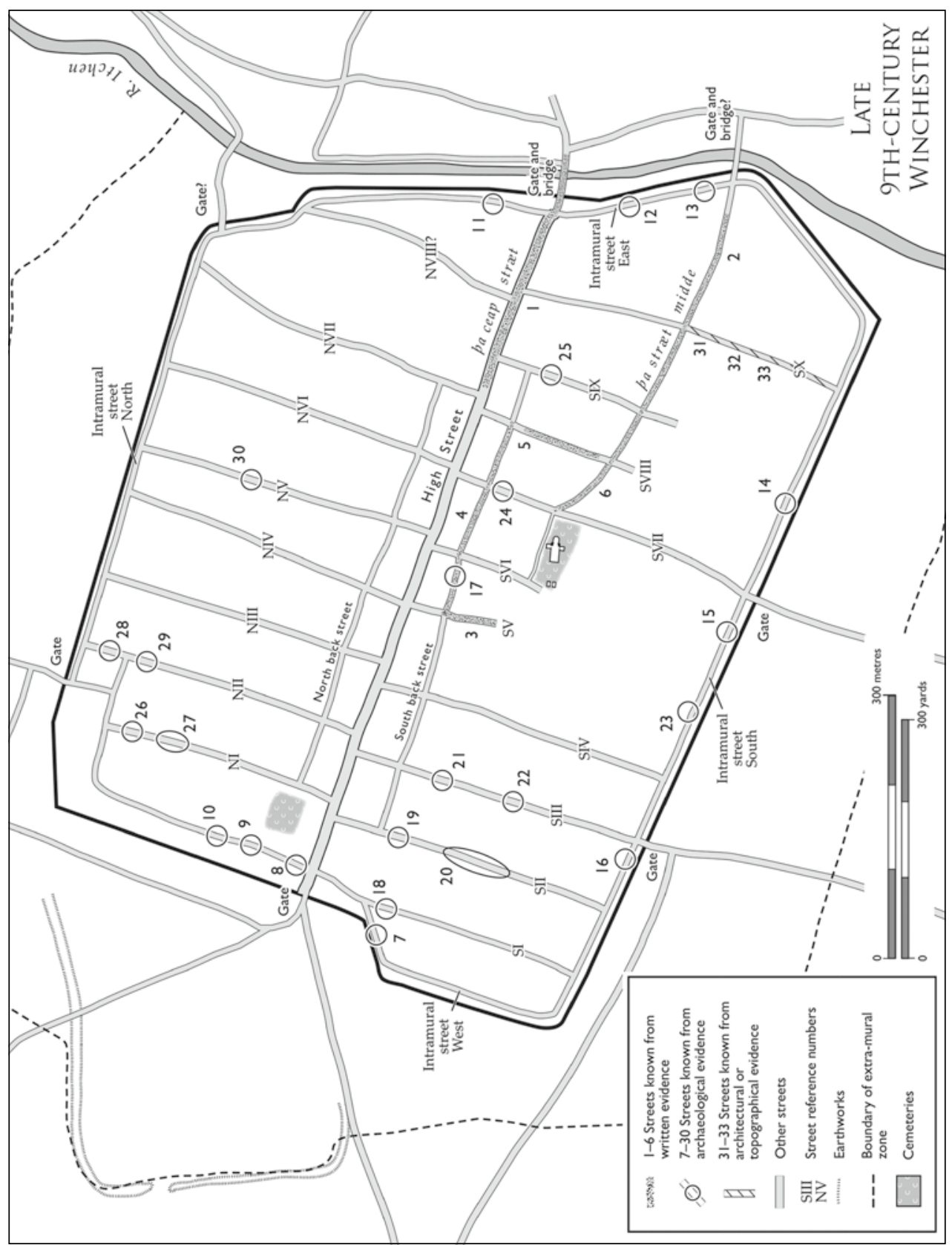

童 


\section{Appendix A: Winchester's Anglo-Saxon Street-plan: Written and Archaeological Evidence ${ }^{22}$}

Entries 1-33 refer to sites numbered on Fig. 2.8.

\section{Written Evidence: Sites 1-6}

1. pa ceap strcet

'the market street', before 5 January 902, ${ }^{23}$ refers to the E part of the later High Street. Cf. London, Westceap, spurious charter of 1067, written ?in early 12th century, but with good OE forms, and eastceape, c.110o. ${ }^{24}$

\section{2. pa strcet midde}

'the mid street', before 5 January $902,{ }^{25}$ probably same as Entry 6.

3. westrichte to ðœere street

'due west to the street', i.e. 'the west street', ?901, ${ }^{26}$ a lost N-S street, see below South v.

\section{4. ðcere norð strcete}

'the north street', ?901, ${ }^{27}$ an E-W street, probably Back-street South, found in excavation, see Entry 17.

\section{5. 万cre east strete}

'the east street', ?901, ${ }^{28}$ a lost N-S street, see below South VIII.

\section{6. ðœеre suð strete}

'the south street, ?901, ${ }^{29}$ an E-W street, probably the same as 'the mid-street', see Entry 2.

22 For further information on the Anglo-Saxon streets, see WS 11, pp. 27-29 and Gazetteer, pp. 68-69.

23 Alexander R. Rumble, Property and Piety in Early Medieval Winchester:Documents relating to the Topography of the Anglo-Saxon and Norman City and its Minsters, Winchester Studies 4.iii (Oxford, 2002), Doc. I, pp. 45-49, Fig. 7 (hereafter WS 4.iii).

24 Eilert Ekwall, Street-Names of the City of London, revised ed. (Oxford, 1965), pp. 182-85.

25 WS 4.iii, Doc. I, pp. 45-49, Fig. 7.

26 WS 4.iii, Doc. II, pp. 50-56, Fig. 8.

27 WS 4.iii, Doc. II, pp. 50-56, Fig. 8.

28 WS 4.iii, Doc. II, pp. 50-56, Fig. 8.

29 WS 4.iii, Doc. II, pp. 50-56, Fig. 8. 


\section{Archaeological Evidence: Sites 7-30}

\section{a. Intra-mural Streets}

\section{Intra-mural Street West}

(NB: the part to the N of High Street is perhaps Snidelingestret ('people living at a place overgrown with coarse grass' $)^{30}$

\section{7. $\quad$ Beneath Castle Yard, 1971}

a street running NE-SW, levelled into and parallel with the Roman rampart behind city wall, and resurfaced at least nine times. Rather less than $2 \mathrm{~m}$ wide, the first surface made of small broken flints, notably similar to the first surface of the adjacent N-S South I, see below Entry $18 .{ }^{31}$

\section{Beneath the S end of Tower Street}

close to the junction with High Street and opposite the SE angle of the new county offices (now Queen Elizabeth II Court), then under construction, in the area of Features $76-80$, of which Feature 79 produced some finds probably of "ninth century" date. It seems to be no more than an assumption that the early street lay here below the south end of Tower Street. ${ }^{32}$

\section{Opposite 56 Tower Street, 1999}

and to the east of the 1964 excavations of the western defences "the insertion of a manhole" 33 revealed a

... thick flint metalling, probably of Roman date ... at a depth of $c .2 .7 \mathrm{~m}$ that directly overlay the natural subsoil. Its substantial nature is indicative of a street that possibly ran north-south, immediately within the line of the western defences of the Roman town. ${ }^{34}$

Given the absence of evidence for the existence of a Roman intra-mural street at Venta, and the small extent of a manhole excavation, this is more likely to be an observation

\footnotetext{
$30 \quad$ WS 1, p. 235.

$31 \quad$ Martin Biddle, "Excavations at Winchester 1971. Tenth and Final Interim Report," AntJ 55 (1975) 103, Fig. 3 (hereafter $x$ Interim).

32 John Collis, Winchester Excavations 1949-1960. Volume II: Excavations in the Suburbs and the Western Part of the Town (Winchester, 1978), p. 201, Fig. 84.

33 David Hopkins, ed., Archaeology in Hampshire: Annual Report 1999, Hampshire County Council (Winchester, 2000), p. 63.

34 A.P. Fitzpatrick, "Roman Britain in 2000: 9. Southern Counties," Britannia 32 (2001), 376.
} 
of a Roman E-W street, perhaps Street 2 (Fig. 2.6), or of Anglo-Saxon Intra-mural street West.

10. Dump of cobbles at east end of Trench III at Tower Street (Final phase 10), 1964 with its W edge $c .15 \mathrm{~m}$ E of inner (E) face of Roman city wall. ${ }^{35}$ If Entries 8 and 9 indicate that the line of Anglo-Saxon Intra-mural street West lay below Tower Street, these cobbles probably lie too far W to be part of the street.

\section{Intra-mural Street North}

No known archaeological evidence at July 2018.

[but see Ward-Evans report in Hampshire Chronicle, 2 July 1938: it is unclear whether this relates to a Roman N-S street or to Intra-mural street North]

\section{Intra-mural Street East (now Colebrook Street East)}

11. $\quad$ 75-79 Eastgate Street, 1989 and 1999

Excavation at three points over a length of about $20 \mathrm{~m}$ revealed a "flint metalled surface" probably representing "the latest use of the medieval intra-mural street ... first constructed on top of the Roman bank as early as the late ninth-century". No dating evidence is reported. ${ }^{36}$

\section{10 Colebrook Street, 1986}

Excavation revealed "a sequence of cobbled surfaces" at the W edge of the excavated site (Phase 4a). Layer 162, the first of the three phases of cobbling, "consisted of a compact surface of tightly packed small and medium-sized flints," probably representing the east edge of the early medieval Colebrook Street. ${ }^{37}$

\section{Magdalen Almshouses, 1980}

Excavation in Trench III revealed

... a possible Roman street $\left(\mathrm{F}_{13}\right)$... on a north-south alignment to the rear of the [Roman] rampart ... the remains of at least three metallings had survived (Phase 301) ... it was at least $3.80 \mathrm{~m}$ wide.

The metallings are described as flint gravel. Phases $303-8$ in Trench III were heavily disturbed by medieval pits and 'truncated' by post-medieval activity. It seems possible that $\mathrm{F} 13$ was in fact a southward continuation of the post-Roman intra-mural

$35 \quad$ III Interim, Pl. LXIX, Layers $2 / 3$.

36 Steven Teague, 75-79 Eastgate Street, Winchester: Report on Archaeological Evaluation 1999 (unpublished in Historic Environment Record [HER], 1999).

37 J. Zant, "The End of the Roman Period," in G. Scobie et al., The Brooks, Winchester. A Preliminary Report on the Excavations, 1987-88, wMs Archaeology Report 1 (Winchester, 1991), pp. 29-31. 
street observed to the $\mathrm{N}$ at $75^{-79}$ Eastgate Street (Entry 11) and 10 Colebrook Street (Entry 12). ${ }^{38}$

\section{Intra-mural Street South}

The central section of this street, from South v, Symonds Street (formerly Minster Street), to the Priory Gate runs along the $S$ face of the Close Wall (for which, see South v). It seems clear that the wall was built to exclude the intra-mural street, which must therefore be older than the construction of the wall. The wall is conventionally dated to the 12 th century. ${ }^{39}$ Its massive simplicity, lacking plinths, buttresses, and freestone quoins, even at the dramatic salient angle at the junction of Symonds Street and St Swithun Street, suggests that the wall may be older, dating perhaps from the time of the establishment of the precincts of the three minsters by King Edgar in $970 .^{40}$

14. Pilgrim's School (within the cathedral precinct), 2005-07

Excavation revealed the presence of a

...spread of tightly packed flint nodules (137) that may have formed a rough track that ran immediately [sic] and parallel to the inside of the [Roman] wall ... It survived for a width of $2.0 \mathrm{~m}$ from the edge of the wall [but may have been wider]. ${ }^{41}$

There was a narrow gully against the wall to the south of the metalled surface (cf. Entry 15) and a second slighter gully to the north.

...It is possible that the metalled surface ... is of [Late Saxon] date, constructed over the slighted Roman rampart along the side of the town wall ... to provide access to the wall to facilitate repairs. ${ }^{42}$

15. $\quad$ 4a St Swithun Street, 1992

Excavation in Trench 2 under Taplin's Building showed that "the Roman rampart was cut into and a coarse metalled surface (F 106) was laid upon the levelled bank." Only a $1.1 \mathrm{~m}$ width of the metalled surface lay within the trench, but "it seems probable that it represents the late Saxon or later intra-mural street, predecessor to St Swithun Street. A small V-shaped ditch (F 109) ... can be seen as a roadside ditch" (cf. Entry 14$) \cdot{ }^{43}$

38 Zant, "End of the Roman Period"(as n. 37).

39 WS 1, pp. 301, 312, and 555.

$40 \quad$ WS 4.iii, pp. 136-39, Document vi. 2.

41 C. Champness et al. "Holocene Environmental Change and Roman Floodplain Management at the Pilgrims' School, Cathedral Close, Winchester, Hampshire," PHFCAS 67:1 (2012), 25-68, at p. 44 .

42 Champness et al., "Holocene Environmental Change and Roman Floodplain Management," pp. 39, 44, and 54, Fig. 13C.

43 Steven Teague, Archaeological Evaluation-4a St Swithun Street, unpublished report in WRU and WMS archives, dated 5 November 1992. 
16. Southgate Street, former Provost Cells, 2013

The excavation of Trench 4 revealed two successive metalled surfaces, the lower of "tightly pack[ed] angular flint cobbles" [Context 404], "probably an intra-mural street and associated with 1oth-12th century pottery ... cut into the Roman bank" [of the southern defences]. ${ }^{44}$

\section{b. Back Streets, Parallel to High Street to North and South}

Back Street North

No known archaeological evidence at July $2018 .{ }^{45}$

\section{Back Street South}

17. $\quad 31 \mathrm{a}-\mathrm{b}$ The Square, 1988

Excavation revealed "a flint metalled surface" running E-W across the S part of the excavated area. The 'road' appeared

... to have been little used since its single surface was unworn and by the 1oth/11th century it was sealed by a thick silty clay deposit. The street probably represents part of the original later Saxon street grid. Its apparent minimal usage and early closure are closely supported by the documentary evidence. ${ }^{46}$

The same as 'the north street', see above, Written evidence, Entry 4.

\section{c. North-south Streets: South of High Street (South $I-X)$}

South I, Beneath Castle Yard, No Known Name.

18. Castle Yard, 1971

the first of eight superimposed street surfaces "was made of a single layer of small broken flints, tightly packed together without any special bedding and forming a hollow surface about $1.5 \mathrm{~m}$ wide." The eighth and latest surface reached a width of not less than $6.7 \mathrm{~m} .^{47}$

44 Steven Teague, Old Guard House and Provost Cells: Evaluation Report, Southgate Street, Winchester, Hampshire, Oxford Archaeology Report, unpublished in HER (2014), Paras. 3.6.7, 4.3.5, and pp. 25-26, Contexts 402 and 404 , not to be confused with the supposed (but probably mis-identified) Roman intra-mural street represented by Context 419 .

45 Ward-Evans observed "traces of a Roman road" under St George's Street in 1931 but it is not clear whether this was an early metalling of St George's Street or of one or both of the Roman N-S streets C or D (see Fig. 2.6): Hampshire Chronicle, 29 August 1931.

$46 \quad$ WMS Newsletter 3 (Feb. 1989), 3-5, Fig. 3.

47 VIII Interim, 285-89, Pls XXXIX, XLa. 


\section{South II, Trafalgar Street}

originally Gerestret (c.1110) probably 'Grass street',48 the most extensively investigated of all Winchester's Anglo-Saxon streets, excavated intermittently over a length of about $150 \mathrm{~m}$.

\section{Assize Courts South, $1964^{49}$}

For the two early 1oth-century coins from the lowest two surfaces of this street, see Appendix B.

\section{Lower Barracks, 1989}

Excavation records show that in 1989 Gar Street was investigated in four trenches, over a total length of $105 \mathrm{~m}$. Both sides of the street were seen, indicating a width of at least $5.6 \mathrm{~m}$, and both appear to have been built up throughout the length examined. ${ }^{50}$ For the coin of Alfred recovered from "one of the earlier levels of a building abutting the street to the east," ${ }^{51}$ see Appendix B.

South III, Southgate Street

originally Goldestret (c. 1110), perhaps 'Goldsmiths' street'.52

21. Hotel du Vin, Southgate Street, 2011

observation of the Winchester Gas Main Project by Wessex Archaeology in 2011 recorded "metalled surfaces," suggested by P.J. Ottaway to be "Anglo-Saxon and medieval?"53

\section{Guard House, Southgate Street, 2011}

observation of the Winchester Gas Main Project by Wessex Archaeology in 2011 recorded "metalled surfaces," suggested by Ottaway to be "Anglo-Saxon and medieval?"54

South IV, St Thomas Street

originally Calpestret (c.1110), meaning unknown. ${ }^{55}$

No known archaeological evidence at July 2018.

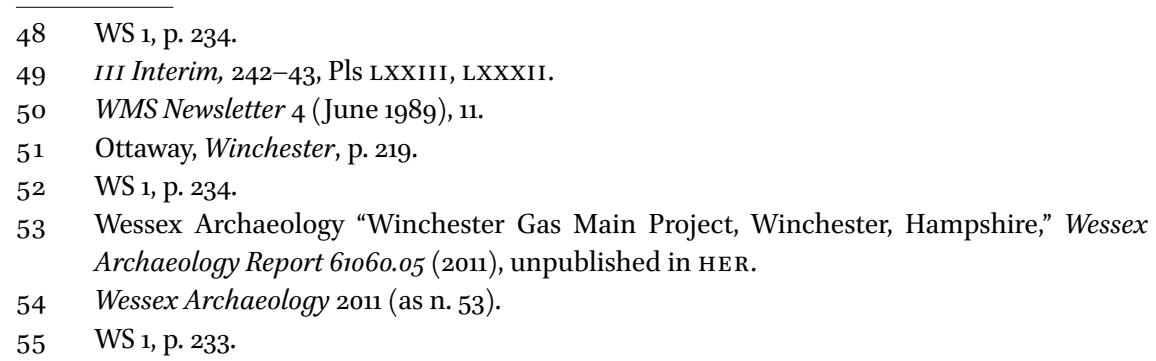


South v, Little Minster Street

originally the north half of Mensterstret (1148), 'Minster Street'.56 Original name unknown, but perhaps to be identified with 'the west street' (see above, Written evidence, Entry 3). Little Minster Street runs S from High Street in a slightly curving line down to the site of the former Minster Gate, at which point it reaches the NW corner of the Close Wall. From here the street runs $\mathrm{S}$ in a straight line down the $\mathrm{W}$ side of the Close Wall. At some date after the foundation of the almshouses of Christ's Hospital under the will of Peter Symonds in 1586, the southern half of Minster Street became known as Symonds Street. ${ }^{57}$ The curving $\mathrm{N}$ half of Minster Street appears to reflect the western limit of the Anglo-Saxon and Norman royal palace, finally abandoned following the siege of Winchester in August 1141. The straight $S$ half of the street respects, as does the E half of St Swithun Street, the wall of the Cathedral Close, a major intact monument, the flint work of which is not later than the 12th century and may be much earlier.

\section{No. 24 St Swithun Street}

In 1929 Ward-Evans recorded in the upper part of a deep excavation in the street opposite Miss Holloway's house (24 St Swithun Street), ${ }^{58}$ "the old Roman roadway".59 An excavation in St Swithun Street at this point will have been as much as $10 \mathrm{~m}$ north of the line of Intra-mural Street South. Since 24 St Swithun Street lies directly opposite the $\mathrm{S}$ end of Symonds Street, the observation probably relates to the $\mathrm{S}$ end of the former Minster Street.

\section{South VI}

Lost street to the E of Little Minster Street, apparently giving entry to the west fronts of the Old and New Minsters.

No known archaeological evidence at July 2018 but see Fig. 2.8 .

\section{South VII}

Appears to lie here approximately one-street's width to the west of Roman N-S Street E, see Fig. 2.6.

\section{Wessex Hotel, 1961}

Excavation in 1961 on the $S$ side of Market Lane in advance of the construction of the hotel, revealed an area of cobbling "on top of Roman Street E". ${ }^{60}$ No metalled surface which might represent South viI was found to the west of the Roman street, but the

\footnotetext{
$56 \quad$ WS 1, p. 234.

57 WS 2, p. 863.

58 Warren's Winchester Directory 1929, 224.

59 Hampshire Chronicle, 5 October 1929.

6o IInterim, 156-57, Pl. ViII A, Fig. 4, Fig. 5, Layer 27.
} 
later arrangement of burials and buildings suggests that a route representing South VII lay on the expected line in this area of the site. ${ }^{61}$

\section{South VIII}

Lost, perhaps 'the east street', see above, Written evidence, Entry 5. Original name unknown.

No known archaeological evidence at July 2018.

\section{South IX}

Lost, beneath Nunnaminster precinct. Original name unknown.

25. Flint metalling found in excavation, 1973

Trench III, Layer 780 at approximately NGR, SU $4839029273 \cdot{ }^{62}$

\section{South X}

Lost, beneath Nunnaminster precinct and Wolvesey. Original name unknown. See below, Architectural and Topographical evidence, Entries 31-33.

\section{d. North-south Streets: North of High Street (North I-IX or X)}

\section{North I}

Staple Gardens, originally Brudenestret (1148), perhaps 'Street of the Brides', ${ }^{63}$ the second most intensively investigated of Winchester's Anglo-Saxon streets after South II (Entries 19-20).

\section{Frederick Place 1960}

excavation north of (the W-E return of) Tower Street, on the line of Staple Gardens, revealed in all three trenches "a layer of small cobbles, compact and heavily rammed in Trenches I and III in the western half of the site, less continuous in Trench II," which could represent a northern continuation of Brudenestret. Overlying layers (especially Layer 17) produced 1oth- and 11th-century pottery including Winchester Ware. ${ }^{64}$

$61 \quad$ WS 4.i, Part III, Chapter 3.iii, Figs 106, 107a, and 107c.

62 Current Archaeology 102 (Nov. 1986), 206; see WS 4.i, Part x, Chapter II. 1. iv, Figs 6A, 128.

63 WS 1, p. 233.

64 John Collis, Winchester Excavations 1949-196o. Volume II: Excavations in the Suburbs and the Western Part of the Town (Winchester, 1978), pp. 165, 178, Figs 68-69, 74 with pottery nos $57-59$. 
27. Staple Gardens, Discovery Centre, $2005^{-0} 7^{65}$

Full excavation by Oxford Archaeology of a $5 \mathrm{~m}$ length of the street, with a width of up to $5 \mathrm{~m}$, and up to seven superimposed surfaces.

Within Properties BW 2 and BW 3 "the earliest surface ... consisted of a single layer of tightly packed small flint cobbles ... which probably formed the base for a directly overlying surface of fine angular flint gravel". Radiocarbon dates of 770-940 (OxA17177) and 780-990 (SUERC-13909) from the silt over these surfaces, recalibrated by Bayesian modelling, "further refined these dates to $770-890$ and $770-920$ respectively ... which would suggest that the street had been in use for a significant period of time before 890 , or at least had been subject to heavy wear." 66

Within Property BW 4 three superimposed surfaces produced "two statistically consistent radiocarbon determinations" of 780-970 (OxA-17173) and 730-970 (sUERC-13907), refined by Bayesian modelling to $830-940 .{ }^{67}$

The discussion concludes that "the dating ... suggests that the street grid was first laid out ... early in Alfred's reign (871-99), or before, rather than during the 880 os or later". ${ }^{68}$

North II

Jewry Street, originally Scowrtenestret, 'Street of the shoemakers'.69

\section{Crown Hotel site}

A length of $2.80 \mathrm{~m}$ of "tightly packed small and medium sized flints" (Layer 472) forming the earliest surface of the west side of the original N-S line of the street (F. 221) was excavated in Trench IV (Phase 531) and recorded in section (Layer 840) in Trench V (Phase 913). ${ }^{70}$

29. No. 28 Jewry Street, 2009-10

A "coin of Alfred, struck by the monyer Lulla between 875 and 880 , [was] found within the earliest levels of a structure alongside the Saxon precursor to Jewry Street". ${ }^{71}$ For the coin, see Appendix B.

65 Ben M. Ford and Steven Teague, Winchester-A City in the Making:Archaeological Excavations between 2002 and 2007 on the Sites of Northgate House, Staple Gardens and the Former Winchester Library, Jewry Street, Oxford Archaeology Monograph 12 (Oxford, 2011), pp. 79-83, 189-90, Figs 3.3-3.7, Table 3.4. For an "Overview of the Scientific Dating Evidence," see pp. $225^{-36}$, esp. pp. $225^{-26}$, 235-36.

66 Ford and Teague, Winchester, p. 189, Table 3.4.

67 Ford and Teague, Winchester, p. 229, Fig. 6.5, cf. Table 3.4

68 Ford and Teague, Winchester, p. 189.

69 WS 1, p. 234.

70 Zant, "End of the Roman Period" (as n. 37).

71 Ford and Teague, Winchester, p. 189. Due to legal dispute no known interim or full publication exists. 


\section{North III}

St Peter Street, originally Alwarnestret (c.1110), 'Æðelwaru's Street', later Fleshmongestret (1293-4 onwards), 'Street of the butchers'. ${ }^{72}$

No known archaeological evidence at July 2018.

\section{North IV}

Parchment Street from late 13th century, originally flcescmangra strcete (996), 'Street of the butchers.'73

No known archaeological evidence at July 2018.

\section{North V}

Upper Brook Street, originally scyldwyrhtana strcete (996), 'Street of the shieldmakers. ${ }^{74}$

\section{Central Car Park, 1978}

An evaluation excavation on the E side of Upper Brook Street (Trench I) revealed "a series of metalled surfaces, of which the earliest probably represented the Late AngloSaxon street." ${ }^{25}$ The $\mathrm{W}$ edge of The Brooks excavation which followed in 1987-88 lay to the $\mathrm{E}$ of the probable E edge of the Anglo-Saxon street. ${ }^{76}$

\section{North VI}

Middle Brook Street, originally Wenegenestret (c. 1110), possibly 'Winegar's Street'. ${ }^{7}$

The E edge of The Brooks excavation of $1987-8$ lay to the $W$ of the probable $W$ edge of the Anglo-Saxon street. ${ }^{78}$

\section{North VII}

Lower Brook Street, originally Tcennerestret (990), 'Street of the tanners. ${ }^{79}$

The E edge of the Lower Brook Street excavations of 1962-71 lay just to the West of the probable W edge of the Anglo-Saxon street which was not directly encountered. ${ }^{80}$

72 WS 1, p. 233. For the use of the name 'Fleshmonger Street', see WS 1, p. 234; WS 11, Gazetteer, 'St Peter's Street,' cf. 'Parchment Street'.

73 WS 1, p. 234; WS 2, p. 55.

74 WS 1, p. 235.

75 WMS archive; not mentioned in Scobie et al., The Brooks, Winchester, (as n. 37).

76 Scobie et al., The Brooks, Winchester, Fig. 27.

77 WS 1, p. 235.

78 Scobie et al., The Brooks, Winchester, Fig. 27.

79 WS 1, p. 235

8o $\quad$ II to $X$ Interim, passim. 
The excavation traced the development of properties along the $\mathrm{W}$ edge of the AngloSaxon street from the 1oth century onwards, but although there was a long sequence of earlier Anglo-Saxon activity on the site, no evidence for its relationship to the street was possible.

\section{North VIII}

Busket Lane, originally Bucchestret (c.1110), possibly 'Street of the bleachers' or 'Street of Bucca', a personal name. ${ }^{81}$

No known archaeological evidence at July 2018.

\section{Architectural and Topographical Evidence: Sites 31-33}

\section{Wolvesey wall (built 1377)}

There are three blocked openings in the wall, the widest of which (Blocked gate III) lies on the line of the lost $\mathrm{N}-\mathrm{S}$ street, South $\mathrm{x} .{ }^{82}$ The blocking is visible from the interior of the Wolvesey precinct in the $\mathrm{S}$ face of the wall and in the $\mathrm{N}$ face from the garden of 26 Colebrook Street. ${ }^{83}$

\section{Wolvesey, Woodmansgate}

The principal entrance to the palace was built $c .115^{8-71}$ on line of $\mathrm{N}-\mathrm{S}$ street, South $\mathrm{X}$, but at a slight angle to it, following the new alignment of the East Hall. ${ }^{84}$ Roman N-S street $\mathrm{G}$ (Fig. 2.6) lies approximately one-street's width to the $\mathrm{E}$ of both the central passage of the gate and of South $\mathrm{x} .^{85}$

\section{Wolvesey}

The West Hall built by Bishop Gifford $c .1100$ on the west side of N-S street, Street $\mathrm{X},{ }^{86}$ can now be seen to have been aligned along it. The later East Hall, built by Bishop Henry of Blois $c .1135$, lies on a slightly different alignment.

\footnotetext{
81 WS 1, p. 233.

82 WS 1, Figs 9, 25-27.

83 Observed by Martin Biddle and Katherine Barclay, 2013-14.

84 WS 7.ii, p. 1204, Fig. 387.

$85 x$ Interim, 321-23, 326, 328, Figs 17-19, Pls 62a-b.

86 WS 1, Figs 9, 25-27.
} 


\section{Appendix B: Winchester: Anglo-Saxon Streets and Anglo-Saxon Coins}

\section{Street South II (Gar Street)}

1. Edward the Elder penny, horizontal type, Winchester style, minted c. 910-15, "continued to circulate well into the second half of the 1oth century." 87 Found on the lowest cobbled surface under 'Street 1' (i.e. on the surface of the earliest street). ${ }^{88}$

2. Kufic dirham, minted $905^{-906.89}$ Found on the surface of 'Street 1 ' (i.e. the second street). ${ }^{90}$

3. Alfred penny, two-line type, of the moneyer Æthelwulf, Winchester style, minted 880-99. ${ }^{91}$ Found in excavations at Lower Barracks 1989, "from one of the earlier levels of a building abutting the street to the east,"92 "associated with a workshop adjacent to Gar street." ${ }^{93}$ For the coin, see Coin Register 20o7, no. $276 .{ }^{94}$

\section{Street North II (Jewry Street)}

1. Alfred penny, cross-and-lozenge (crossbar) type, of the moneyer Lulla, struck between 875 and $880 .{ }^{95}$ Found in excavations at 28 Jewry Street "within the earliest levels of a structure alongside the Saxon precursor to Jewry Street." ${ }^{\text {96 }}$ For the coin, see Coin Register 2010, no. $194{ }^{97}$

$87 \quad$ Martin Biddle, ed., The Winchester Mint and Coins and Related Finds from the Excavations of 1961-71, Winchester Studies 8 (Oxford, 2012), p. 613, No. 6. (hereafter WS 8)

88 III Interim, p. 242, Pl. LXXXII.

89 WS 8, pp. 695-98.

9o III Interim, p. 242, Pl. LXXXII.

91 Early Medieval Coin Catalogue [EмC] number 2007.00o1. Type N 639 in Jeffrey. J. North, English Hammered Coinage, I: Early Anglo-Saxon to Henry III c.6oo-1272, 3rd ed. (London, 1994).

92 Ottaway, Winchester, p. 219.

93 Ford and Teague, Winchester, p. 189.

94 British Numismatic Journal 77 (2007), 331.

95 EMC 2009.0123. Type N 629 in North, English Hammered Coinage, I (as n. 91).

96 Ford and Teague, Winchester, p. 189.

97 British Numismatic Journal 80 (2010), 225. 